\title{
DYNAMICS OF GLYCOSAMINOGLYCANS CONTENT IN THE TESTES OF RATS AFTER ADMINISTRATION OF NATURAL HERBAL PRODUCTS*
}

\author{
N. M. Brechkaํ, V. O. Bondarenko ${ }^{1}$ Ye. M. Korenieva ${ }^{1}$, Yu. B. Laryanovskaya ${ }^{2}$, \\ D. V. Morozenko², V. V. Kozar², N. A. Ashukina ${ }^{3}$, F. S. Leontieva ${ }^{3}$, \\ E. V. Shcherbak ${ }^{4}$, S. V. Ivannikova ${ }^{5}$ \\ ${ }^{1}$ SI «V. Danilevsky Institute for Endocrine Pathology Problems of NAMS of Ukraine», Kharkiv, Ukraine; \\ ${ }^{2}$ National University of Pharmacy, Kharkiv, Ukraine; \\ ${ }^{3}$ Sytenko Institute of Spine and Joint Pathology NAMS of Ukraine, Kharkiv, Ukraine; \\ ${ }^{4}$ Kharkiv State Zoo-Veterinary Academy, Kharkiv, Ukraine; \\ ${ }^{5}$ Private Company "ALVIS-CLASS", clinico-diagnostic laboratory, Kharkiv, Ukraine \\ natalia01073@gmail.com
}

According to the results of a modern study of the frequency of action of factors that can affect spermatogenesis (Androbase ${ }^{\circledR}$ database), the cause of male infertility is often unknown. In this case varicocele, hypogonadism, infectious diseases of the male genital organs and cryptorchidism are the most common diseases in pathozoospermia $(14.8 \% ; 10.1 \% ; 9.3 \%$, and $8.4 \%$, respectively) [1].

It is possible that testicular dysfunctions, including idiopathic infertility in men, may be caused by changes in connective tissue [2,3], which are characterized by disorders of its metabolism, the content of collagen and glycosaminoglycans (GAGs) [4, 5]. Such patients quite often have the anomalies of the genital system. It is the anomalies in the development of connective tissue structures of the venous wall and not compensated state of the valve apparatus that lead to varicocele. The prevalence of varicocele among infertile patients reaches $40 \%$, whereas male population in general has this disease only in $15 \%$ of cases $[4,5]$.

It is known that human spermoplasm has a molecular composition that is not inferior in complexity to blood serum (Petrunin D.D. et al., 1996; Loko F., 2001). One of its features is a high concentration of proteoglycans which are high molecular weight carbohydrate-protein compounds. They are among the most fully studied biochemical components of human tissues with the exception of the reproductive

* The research was carried out as part of investigation work at the SI «V. Danilevsky Institute for Endocrine Pathology Problems of National Academy of Medical Science of Ukraine» «Optimization of the diagnosis and treatment of reproductive health disorders endocrine genesis in young people» (State registration number: 0111U000177).

Institution, which financed the research: National Academy of Medical Science of Ukraine.

The authors assume responsibility for the published work.

The authors guarantee absence of competing interests and their own financial interest when carrying out the research and writing the article.

The manuscript was received by the editorial staff 14.02.2020. 
system (Nikolaev A. A., 2000; Gainullina L. H. et al., 2003). According to the research of R. V. Vetoshkin $[6,7]$, the concentration of proteoglycans in the rats' spermoplasma averages 0.77-0.82 $\mathrm{mg} / \mathrm{ml}$. These compounds in the spermoplasma are composed of approximately $70 \%$ of Chondroitin sulfate proteoglycans and only $30 \%$ of Heparan sulfate proteoglycans.

Today it has been proven that spermiogenic epithelium and Sertoli cells also synthesize glycosaminoglycans, which are then secreted into ejaculates. Chondroitin-4-sulfate, Chondroitin6 -sulfate, Keratansulfate and hyaluronic acid are known to be components of the tissue of epididymis and testes of rats [2]. Song X. X. et al. in their research showed the effect of Chondroitin sulfate $\mathrm{C}$ on the capacity and parameters of fertilization of sperm in animals in vitro [8]. The study showed that chondroitin sulfate $\mathrm{C}$ was an effective factor in the activity of sperm in pigs and could transfer sperm from the condensed state and consequently prevent the germ cells from spontaneous acrosome reaction, which facilitates their penetration into the oocyte. According to the research conducted by Makolinets K.V. et al., chondroitin sulfates can be used as biochemical markers of GAG metabolism [9]. Changes in GAG content may reflect the functional status of the semen, which ensures normal spermatogenesis. Therefore, the study of this indicator can be used to explain the mechanisms of infertility and to find ways to correct both hypo- and infertile conditions in men.

Therefore, the aim of our work was to study the content of glycosaminoglycans in the samples of the testes affected with serotonin hydrochloride and correction of this condition with such drugs as Tribestan, Chondroitin sulfate and Bioglobin-U.

\section{MATERIALS AND METHODS}

Animals were kept in the vivarium of the State Institution «V. Danilevsky Institute for Endocrine Pathology Problems of NAMS of Ukraine» in natural light and standard diet recommended for this species of animals and with water access ad libitum. The study was performed on sexually mature male rats weighing 280-350 $\mathrm{g}$ of the Wistar population. A serotonin lesion model was used to obtain the pathology of the testes; rats were given Serotonin hydrochloride (Alfa Aesar ${ }^{\circledR}$ ) for 14 days, subcutaneously at a dose of $5 \mathrm{mg} / \mathrm{kg}$ body weight).

In the mechanism of the testes pathology model development, a leading role is played by the vasoconstrictive effect of serotonin hydrochloride which causes the disturbed trophic and pathological changes observed in varicocele in men, traumas and congestion in the gonads, etc. [10]. As noted in previous studies, Serotonin hydrochloride at a dose of $5 \mathrm{mg} / \mathrm{kg}$ body weight disrupts the metabolism of Sertoli and Ladig cells in rats. During the reproduction of this pathology, the synthetic and reparative activity of the testes decreased, as a consequence there was fragmentation of membranes of the endoplasmic reticulum, reduction of the number of ribosomes, polys and secretory granules, increase in the number of secondary ly- sosomes, as well as reduction of lamellar cytoplasmic degeneration, and decrease in the level of testosterone [11].

The reference drug was Tribestan, which is prescribed for the treatment of hypogonadism, disorders of spermatogenesis, namely oligo- and asthenospermia, which includes an extract of anchors (Tribulus terrestris) containing steroid saponins of furastanol type. The drug restores Leydig cells, stimulates spermatogenesis, increases sperm count, increases sperm motility [12].

Chondroitin sulfate, "Bioglobin-U» and Tribestan were given three days before the start of Serotonin hydrochloride administration, during Serotonin administration (14 days) and for three days after the last Serotonin injection once daily.

The animals were divided into six groups: the $1^{\text {st }}$ group was intact control; the $2^{\text {nd }}$ was control pathology, i.e. a pathology of the semen, in which animals were administered serotonin hydrochloride (Alfa Aesar ${ }^{\circledR}$ ) for 14 days subcutaneously at a dose of $5 \mathrm{mg} / \mathrm{kg}$ body weight; the $3^{\text {rd }}$ group was control pathology + Tribestan (manufactured by Sopharma, Bulgaria) at a dose of $60 \mathrm{mg} / \mathrm{kg}$ body weight; the $4^{\text {th }}$ group was control pathology + substance Chondroitin sulfate (manufactured by "Sigma», USA), at 
a dose of $60 \mathrm{mg} / \mathrm{kg}$ body weight; the $5^{\text {th }}$ group was control pathology + «Bioglobin-U» (manufactured by CJSC «Biolik», Kharkiv), at a dose of $200 \mathrm{\mu l} / \mathrm{kg}$ body weight; and the $6^{\text {th }}$ group was control pathology + substance Chondroitin sulfate + Tribestan in the above specified dose. The euthanasia of rats was performed on the $21^{\text {st }}$ day of the experiment, the testes were isolated. There are 8 male rats in each group.

In this work we performed histochemical studies of rat testes. For the histochemical study of GAGs content in the samples of testes, they were fixed in $10 \%$ formalin solution, dehydrated in alcohols of increasing strength and poured into paraffin. Detection of GAGs on sections was a metachromatic reaction by staining with toluidine blue at $\mathrm{pH}$ 2.5: there occurred a change in color from blue to purple color of various degrees of saturation due to the combination of a high degree of dissociation of the acid groups of the substrate [13]. The degree of color saturation was evaluated according to the principle of cell counting in histological samples using a semi-quantitative method for visual assessment of the color intensity of microstructures during histochemical reactions [14]. A quantitative assessment of the degree of color intensity was expressed in points:

1) orthochromatic reaction -0 point;

2) low metachromatic reaction -1 point;

3) average metachromatic reaction -2 points;

4) significant metachromatic reaction 3 points;

5) extremely significant metachromatic reaction -4 points.

The investigation has been carried out according to the National «General Principles for Animal Research Ethics» (Ukraine, 2001) which corresponds to the "European Convention for the Protection of Vertebrate Animals used for Experimental and Other Scientific Purposes», (Strasburg, 1985), and "Guide for Research Ethic Committee», 2012.

The data was processed using the software package "Statistica v. 10.0». If the data were not consistent with the normal distribution, the comparison of indicators was performed according to the non-parametric Wilcoxon criterion with calculation of the median $(\mathrm{Me})$ and percentiles (25\% and $75 \%$ ). Critical level of significance was assumed to be equal to or less than $0.05(\mathrm{p}<0.05)$.

\section{RESULTS AND THEIR DISCUSSION}

In the gonads of intact rats, violet staining in the ribbon of the spermatogenic epithelium was detected in the tubules by staining with toluidine blue. Small areas of metachromasia (the same purple color) were visualized in the inter-canal stroma, indicating the presence of GAGs. The degree of color saturation was $4.00 \pm 0.53(3.30 \div 0.00)$ points. The intact connective tissue in young intact adult rats (body weight 280-350 g) was combined with the normal morphological condition of the testes, which tracked all stages of spermatogenesis and their functional activity (namely, the normal level of sex hormones, quantitative and qualitative indicators of spermatogenesis).

Reproduction of Serotonin pathology of gonads in the seminiferous tubules and intercranial stroma shows an orthochromatic reaction (almost complete absence of purple color) when staining with toluidine blue, which advocates a deficiency of GAGs compared with intact control (Fig. 1). The degree of color saturation was
$0.00 \pm 0.20(0.00 \div 0.08)$ points. Such a histochemical picture in serotonin lesions of the testes may explain the fact that the level of Tc decreases in the animals with experimental (control) pathology, because the decrease in the amount of loose connective tissue providing «nutrition» of Leydig cells in the intact animals, probably, led to the reduction of their functional activity level. Violation of the functional state of the testes in case of serotonin loading was reported by other authors [10] and by us in earlier research [11].

In addition, as it was expected, serotonin causes significant submicroscopic changes of the organisms of glondulocytes and dystrophicdestructive disorders in the ultrastructure of their mitochondria accompanied by hypotestosteronemia. Moreover, animals with serotonin pathology had an intensive decrease in the number of ribosomes and polysomes in the cytoplasm of Sertoli cells [11], the so-called supporting cells, which also ensure the normal 

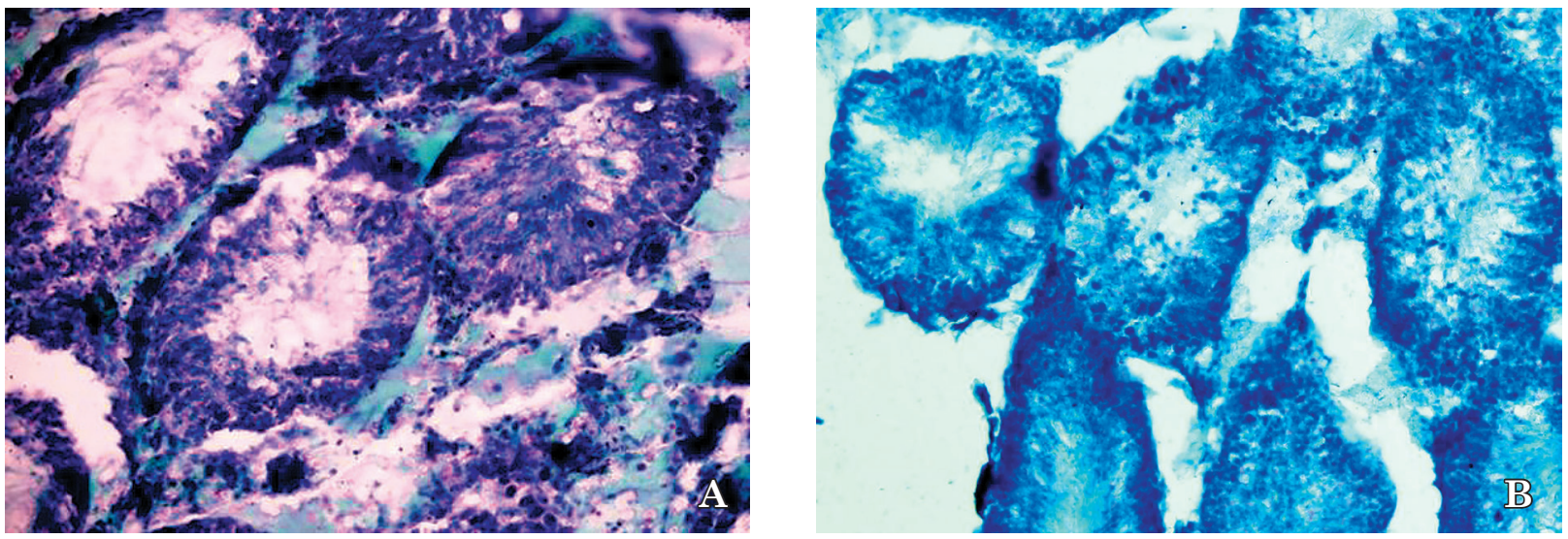

Fig. 1. Histological sections of testis tissue of rats:

A - intact control $(\times 250)$; B - after the administration of serotonin $(\times 250)$.

Metachromatic reaction with toluidine blue.
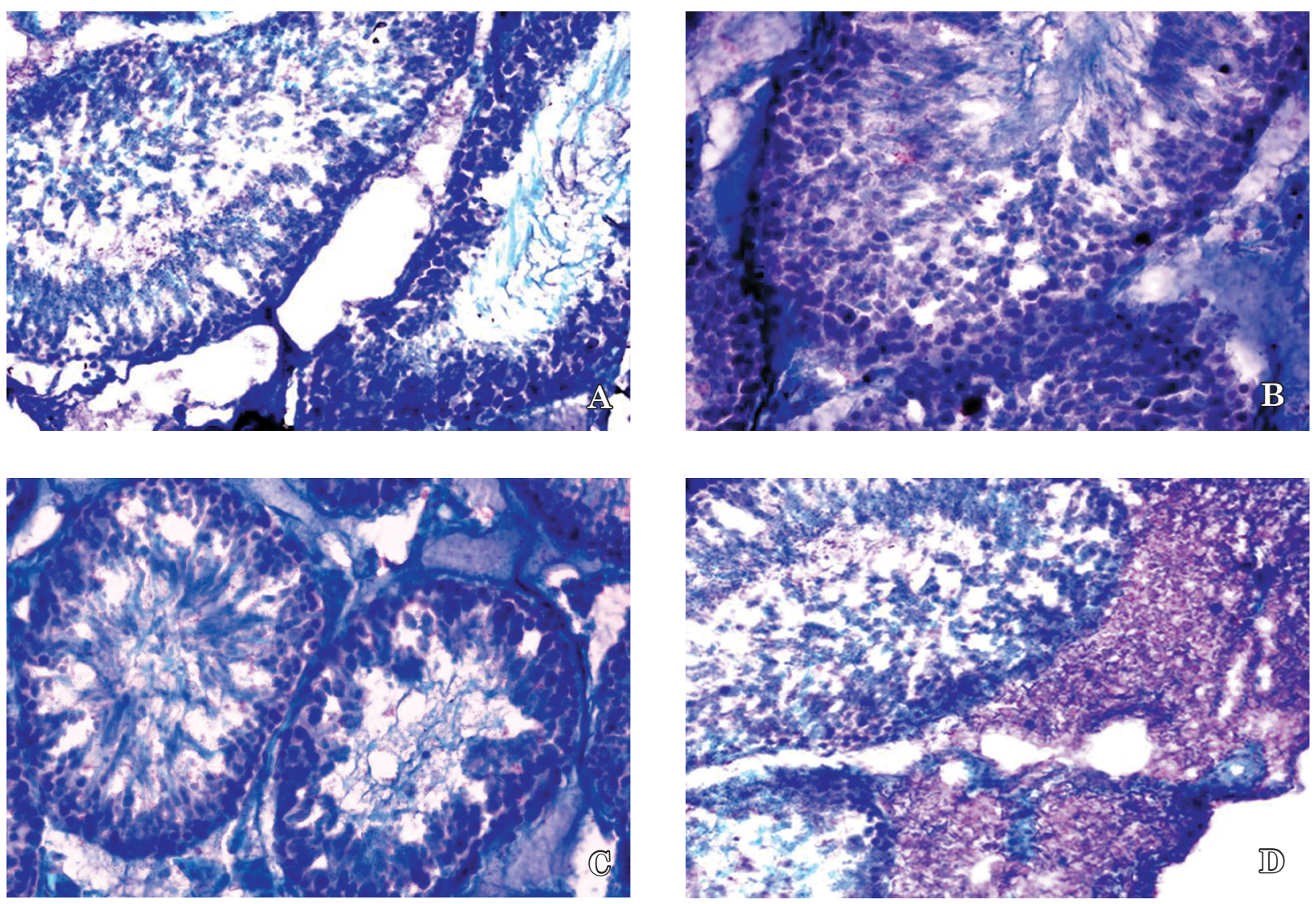

Fig. 2. Histological sections of tissue of rats' testes

after administration of serotonin and using natural herbal products:

A - Chondroitin sulfate $(\times 400)$; B - Bioglobin U (× 400); C - Tribestan $(\times 400)$;

D - Chondroitin sulfate and Tribestan $(\times 250)$. Metachromatic reaction with toluidine blue.

state of spermatogonia and other spermatogenesis cells. The decrease of ribosomes and polysomes in the cytoplasm of Sertoli cells together with a very small number of GAGs, may cause abnormality of spermogram.

Chondroitin sulfate, administered to rats with serotonin pathology of the testes, signifi- cantly increased the content of GAGs in the intercranial stroma and in the tubules, as evidenced by the presence of purple staining zones in the intercranial stroma and areas of location of the germ cells (Fig. 1). The degree of color saturation in this group of animals was $3.00 \pm$ $0.33(3.00 \div 3.00)$ points. 
Administration of Bioglobin-U, together with serotonin was also accompanied by a rather pronounced metachromatic reaction visualized in the tubules and inter-canal stroma, which indicated an increase of GAGs under such experimental conditions (Fig. 2). The degree of color saturation was $3.00 \pm 0.33(3.00 \div 3.00)$ points.

Tribestan administration to animals with experimental gonadopathy, contributed to the appearance of metachromatic zones in the ribbon of the spermatogenic epithelium and intercranial stroma, but the severity of the reaction was moderate, especially $2.00 \pm 0.00(2.00 \div$ $2.00)$ points. However, the combined administration of Chondroitin sulfate and Tribestan to rats with serotonin pathology of the testes contributed to the increase of metachromasia in the inter-canal stroma compared with the separate administration of these substances (Fig. 2). The degree of color saturation in this group of animals was $3.50 \pm 0.33(3.00 \div$
4.00) points. The restoration of the quantitative content of chondroitin sulfates in the testes of rats coincided with the revealed increase in the degree of metachromasia according to the histological examination, which indicated the interrelation of the GAGs content in the spermiogenic epithelium, and may be the basis for a more complete restoration of the functional state of testes and potentiate Tribestan action for some forms of infertility. Morphological and histological examinations of gonadopathy animals treated with Chondroitin sulfate, Bioglobin-U, Tribestan, and Tribbestan + Chondroitin sulfate correlate with spermatogenesis and male sex hormone level previously determined in these animals $[14,15]$.

Thus, the results of histochemical examination of rats' testicular tissues by chondroitin sulfate content may indicate a positive effect of GAG-containing drugs, in particular, Chondroitin sulfate and "Bioglobin-U», on the morpho-functional state of gonads in rats.

\section{CONCLUSIONS}

1. The histochemical methods and metachromatic reaction with toluidine blue showed that intact sexually mature male rats' testes had a sufficient number of glycosaminoglycans, which was visualized in the tape of the spermatogenic epithelium and small areas of metachromaticemia.

2 . The results of histochemical study of glycosaminoglycans content in animals with induced gonadopathy by administration of serotonin hydrochloride indicated glycosaminoglycans deficiency.

3. Administration of Chondroitin sulfate, «Bioglobin-U» and Tribestan during serotonin lesions of the testes significantly increased glycosaminoglycans in the tubules and intercranial stroma.

\section{REFERENCES}

1. Nieschlag E, Behre HM, Nieschlag S. Male reproductive health and dysfunction, Berlin, 2010; Ch. 5: 83-87.

2. Tjabut TD, Karatysh OM. Sovremennaja Revmatologija 2009; 3(2): 19-23. doi: 10.14412/1996-7012-2009-534.

3. Agarwal A, Esteves SC. Asian J Androl 2016; 18(2): 161162. doi: 10.4103/1008-682X.172819.

4. Sobennikov IS, Zhiborev BN, Kotans Sja, Cherenkov AA. Ros med-biol vestn im. akad. I.P. Pavlova 2017; 25(3): 460-464.

5. Omel'janenko NP, Sluckij LI. Soedinitel'naja tkan': (gistofiziologija i biohimija), Moskva, 2009: $380 \mathrm{p}$.

6. Vetoshkin RV. Proteoglikany i glikozaminoglikany reproduktivnoj sistemy samcov krys pri hronicheskom vozdejstvii prirodnyh toksikantov, Astrahan', 2016: 133 p.

7. Vetoshkin RV, Nikolaev AA, Loginov PV. Problemy Reprodukcii 2012; 2: 16-17.

8. Song XX, Xu Z, Piao YJ, et al. Anim Reprod Sci 2008; 108(1-2): 144-156. doi: 10.1016/j.anireprosci.2007.07.010.
9. Makolinets KV, Makolinets VI, Morozenko DV, et al. Wiad Lek. 2019; 72(2): 193-197.

10. Zajchenko GV, Jakovljeva LV, Butenko IG, Larjanovs'ka JuB. Farmakologija ta likars'ka toksykologija 2008; 1-3: 74-79.

11. Brechka NM, Nevzorov VP, Bondarenko VO, et al. Fiziol Zhurn 2015; 61(4): 93-99.

12. Gorpinchenko II, Gurzhenko JuN, Spiridonenko VV, Gurzhenko AJu. Zdorov'e Muzhchiny 2012; 3: 72-74.

13. Kern M, Modish L, Deduh NV, et al. Arhiv anatomii, gistologii i jembriologii. 1985; 88(6): 5-12.

14. Sokolovskij VV. Gistohimicheskie issledovanija v toksikologii. Polukolichestvennaja vizual'naja ocenka intensivnosti okraski mikrostruktur pri gistohimicheskih reakcijah, Leningrad, 1971: $176 \mathrm{p}$.

15. Brechka NM, Bondarenko VO, Korenjeva JeM, et al. Eksperym Klin Medycyna 2012; 3(56): 52-58. 


\section{ДИНАМІКА ВМІСТУ ГЛІКОЗАМІНОГЛІКАНІВ У СІМ'ЯНИКАХ ЩУРІВ ПІСЛЯ ВВЕДЕННЯ ПРЕПАРАТІВ ПРИРОДНОГО ПОХОДЖЕННЯ}

Бречка Н. М. ${ }^{1}$, Бондаренко В. О. ${ }^{1}$, Коренева Є. М. ${ }^{1}$, Лар'яновська Ю. Б. ${ }^{2}$, Морозенко Д. В. ${ }^{2}$, Козар В. В. ${ }^{2}$, Ашукіна Н.O. ${ }^{3}$, Леонтьева Ф. С. ${ }^{3}$, Щербак О. В. ${ }^{4}$, Іваннікова С. В. ${ }^{5}$

${ }^{1}$ ДУ «Інститут проблел ендокринної патології іл. В. Я. Данилевського НАМН Украйни», м. Харків, Україна;

${ }^{2}$ Національний фармацевтичний університет, м. Харків, Украӥна;

${ }^{3}$ ДУ «Інститут патології хребта та суглобів ім. проф. М. І. Ситенка НАМН України», м. Харків, Україна;

${ }^{4}$ Харківська державна зооветеринарна академія, м. Харків, Украӥна;

${ }^{5}$ Клініко-діагностична лабораторія "АЛВІС-КЛАС», м. Харків, Украӥна natalia01073@gmail.com

Важають, що тестикулярні дисфункції, у тому числі й ідіопатичної неплідності у чоловіків, можуть бути викликані змінами у сполучній тканині, які характеризуються порушеннями їі метаболізму, зокрема вмісту колагену і глікозаміногліканів. Зміни вмісту глікозаміногліканів можуть бути відображенням функціонального стану сім'яників, який забезпечуе нормальний сперматогенез. Дослідження цього показника може бути використано для пояснення механізмів безпліддя та пошуку засобів корекції як гіпо-, так і інфертильних станів у чоловіків.

Метою нашої роботи було дослідження вмісту глікозаміногліканів у зразках сім'яників при ураженні ї серотоніну гідрохлоридом та корекції цього стану препаратами Трибестан, Хондроїтину сульфрату та «Біоглобіну-У».

Методи. Для відтворення патології гонад була використана модель серотонінового ураження яєчка: щури самці отримували серотоніну гідрохлорид, протягом 14-ти діб підшкірно у дозі 5 мг/кг маси тіла). Гістохімічні дослідження проводили у дорослих самців щурів, що отримували серотоніну гідрохлорид та тих, яким на тлі його вводили препарати Хондроїтину сульфат у дозі 60 мг/кг маси тіла, «Біоглобіна-У» в дозі 200 мкл/кг маси тіла та Трибестан - 60 мг/кг маси тіла. Виявлення ГАГ на зрізах відображали як реакцію метахромазії шляхом фрарбування толуїдиновим синім при рН 2,5.

Результати. Було показано, що у інтактних статевозрілих самців щурів в сім'яниках гістохімічними методами виявляеться виразна реакція метохромазії з толуїдиновим синім, що свдчить про достатню кількість глікозаміногліканів в стрічці сперматогенного епітелію у міжканальцевій стромі. Результати гістохімічного дослідження вмісту глікозаміногліканів у тварин, у яких була викликана гонадопатія шляхом введення серотоніну гідрохлориду, свідчать про їх дефіцит. При введенні препаратів Хондроїтину сульфат, «Біоглобіну-У» та Трибестану на тлі серотонінового ураження сім'яників відбувається значне підвищення вмісту глікозаміногліканів у сім'яних канальцях та міжканальцевій стромі.

К л ючові слова: Хондроїтину сульфат, серотоніну гідрохлорид, варикоцеле, гликозаміноглікани, метахромазія, сперматозоїди.

\section{ДИНАМИКА СОДЕРЖАНИЯ ГЛИКОЗАМИНОГЛИКАНОВ В СЕМЕННИКАХ КРЫС ПОСЛЕ ВВЕДЕНИЯ ПРЕПАРАТОВ ПРИРОДНОГО ПРОИСХОЖДЕНИЯ}

Бречка Н. М. ${ }^{1}$, Бондаренко В. А. ${ }^{1}$, Коренева Е. М. ${ }^{1}$, Ларьяновская Ю. Б. ${ }^{2}$, Морозенко Д. В. ${ }^{2}$,

Козар В. В. ${ }^{2}$, Ашукина Н. А. ${ }^{3}$, Леонтьева Ф. С. ${ }^{3}$, Щербак О. В. ${ }^{4}$, Иванникова С. В. ${ }^{5}$

${ }^{1}$ ГУ «Институт проблел эндокринной патологии ил. В. Я. Данилевского НАМН Украины», г. Харьков, Украина;

${ }^{2}$ Национальный фбармацевтический университет, г. Харьков, Украина;

${ }^{3}$ ГУ «Институт патологии позвоночника и суставов им. профб. М. И. Ситенко НАМН Украинь»,, г. Харьков, Украина;

${ }^{4}$ Харьковская государственная зооветеринарная академия, г. Харьков, Украина;

${ }^{5}$ Клинико-диагностическая лаборатория "АЛВИС-КЛАСС», г. Харьков, Украина natalia01073@gmail.com

Считают, что тестикулярные дисфункции, в том числе и идиопатическое бесплодие у мужчин, могут быть вызваны изменениями в соединительной ткани, характеризующиеся нарушениями ее метаболизма, в частности содержания коллагена и гликозаминогликанов. Изменения содержания гликозаминогликанов являются отражением функционального состояния семенников, который обеспечивает нормальный сперматогенез. Исследование этого показателя можно использовать для объяснения механизмов бесплодия и поиска средств коррекции как гипо-, так и инфертильних состояний у мужчин.

Целью нашей работы было исследование содержания гликозаминогликанов в образцах семенников при поражении серотонина гидрохлоридом и коррекцией этого состояния препаратами Трибестан, Хондроитина сульфата и «Биоглобина-У». 
Методы. Для воспроизведения патологии гонад была использована модель серотонинового поражения семенников: крысы самцы получали серотонина гидрохлорид, в течение 14-ти суток подкожно в дозе 5 мг/кг массы тела. Проведены гистохимические исследования содержания гликозаминогликанов на срезах, составлявших реакцию метахромазии, путем окрашивания толуидиновым синим, у взрослых самцов крыс, получавших серотонина гидрохлорид и тех, которым на его фроне вводили препараты Хондроитина сульфат в дозе 60 мг/кг массы тела, «Биоглобина-У» в дозе 200 мкл/кг массы тела и Трибестан - 60 мг/кг массы тела. Обнаружение ГАГ на срезах отражали как реакцию метахромазии путем окрашивания толуидиновым синим при $\mathrm{pH} 2,5$.

Результаты. Было показано, что у интактных половозрелых самцов крыс в семенниках гистохимическими методами наблюдается выразительная реакция метохромазии с толуидиновым синим, что свидетельствует о достаточном количестве гликозаминогликанов в ленте сперматогенного эпителия и в межканальцевой строме. Результаты гистохимического исследования содержания гликозаминогликанов у животных, у которых была вызвана гонадопатия путем введения серотонина гидрохлорида, свидетельствуют о их дефиците. При введении препаратов Хондроитина сульфата, «Биоглобина-У» и Трибестана на фоне серотонинового поражения семенников происходит значительное повышение содержания гликозаминогликанов в семенных канальцах и межкаканальцевой строме.

Ключевые слова: Хондроитина сульфат, серотонина гидрохлорид, варикоцеле, гликозаминогликаны, метахромазия, сперматозоиды.

\section{DYNAMICS OF GLYCOSAMINOGLYCANS CONTENT IN THE TESTES OF RATS AFTER ADMINISTRATION OF NATURAL HERBAL PRODUCTS}

N. M. Brechka' , V. O. Bondarenko ${ }^{1}$, Ye. M. Korenieva ${ }^{1}$, Yu. B. Laryanovskaya ${ }^{2}$, D. V. Morozenko ${ }^{2}$, V. V. Kozar ${ }^{2}$, N. A. Ashukina ${ }^{3}$, F. S. Leontieva ${ }^{3}$, E. V. Shcherbak ${ }^{4}$, S. V. Ivannikova ${ }^{5}$

${ }^{1} S I$ «V. Danilevsky Institute for Endocrine Pathology Problems of NAMS of Ukraine», Kharkiv, Ukraine;

${ }^{2}$ National University of Pharmacy, Kharkiv, Ukraine;

${ }^{3}$ Sytenko Institute of Spine and Joint Pathology NAMS of Ukraine, Kharkiv, Ukraine;

${ }^{4}$ Kharkiv State Zoo-Veterinary Academy, Kharkiv, Ukraine;

${ }^{5}$ Private Company "ALVIS-CLASS», clinico-diagnostic laboratory, Kharkiv, Ukraine natalia01073@gmail.com

It is possible that testicular dysfunctions, including idiopathic infertility in men, may be caused by changes in connective tissue, which are characterized by disorders of its metabolism, the content of collagen and glycosaminoglycans (GAGs). Such patients quite often have the anomalies of the genital system. It is the anomalies in the development of connective tissue structures of the venous wall and not compensated state of the valve apparatus that lead to varicocele. The prevalence of varicocele among infertile patients reaches $40 \%$, whereas male population in general has this disease only in $15 \%$ of cases. Changes in GAG content may reflect the functional status of the semen, which ensures normal spermatogenesis. Therefore, the study of this indicator can be used to explain the mechanisms of infertility and to find ways to correct both hypo- and infertile conditions in men.

Therefore, the aim of our work was to study the content of glycosaminoglycans in the samples of the testes affected with serotonin hydrochloride and correction of this condition with such drugs as Tribestan, Chondroitin sulfate and Bioglobin-U.

Materials. A serotonin lesion model was used to obtain the pathology of the testes; rats were given Serotonin hydrochloride (Alfa Aesar ${ }^{\circledR}$ ) for 14 days, subcutaneously at a dose of $5 \mathrm{mg} / \mathrm{kg}$ of body weight) and on the background of it was administered Chondroitin sulfate at a dose of $60 \mathrm{mg} / \mathrm{kg}$ of body weight, Bioglobin-U at a dose of $200 \mu \mathrm{l} / \mathrm{kg}$ of body weight and Tribestan $-60 \mathrm{mg} / \mathrm{kg}$ of body weight. In this work we performed histochemical studies of rat testes. For the histochemical study of GAGs content in the samples of testes, they were fixed in $10 \%$ formalin solution, dehydrated in alcohols of increasing strength and poured into paraffin. Detection of GAGs on sections was a metachromatic reaction by staining with toluidine blue at $\mathrm{pH} 2.5$ : there occurred a change in color from blue to purple color of various degrees of saturation due to the combination of a high degree of dissociation of the acid groups of the substrate.

Results. It was shown the histochemical methods and metachromatic reaction with toluidine blue showed that intact sexually mature male rats' testes had a sufficient number of glycosaminoglycans, which was visualized in the tape of the spermatogenic epithelium and small areas of metachromaticemia. The results of histochemical study of glycosaminoglycans content in animals with induced gonadopathy by administration of serotonin hydrochloride indicated glycosaminoglycans deficiency. Administration of Chondroitin sulfate, "Bioglobin-U» and Tribestan during serotonin lesions of the testes significantly increased glycosaminoglycans in the tubules and intercranial stroma.

Key words: Chondroitin sulfate, Serotonin hydrochloride, varicocele, glycosaminoglycans, metachromatic reaction, sperm. 